Haya: The Saudi Journal of Life Sciences

Abbreviated Key Title: Haya Saudi J Life Sci

ISSN 2415-623X (Print) |ISSN 2415-6221 (Online)

Scholars Middle East Publishers, Dubai, United Arab Emirates

Journal homepage: https://saudijournals.com

Original Research Article

\title{
Comparative Study of the Antibacterial Potential of Phragmanthera Capitata (Sprengel) S. Balle (Loranthaceae) Extracts, a Parasitic Plant Collected From Three Host Trees
}

Ladoh-Yemeda Christelle Flora ${ }^{1,2^{*}}$, Ngoule Charles Christian ${ }^{2}$, Ngene Jean Pierre ${ }^{2}$, Ndjip Rosette Christelle ${ }^{3}$, Nyegue Maximillienne Ascension ${ }^{4}$, Tomedi Eyango Minette ${ }^{5}$, Ndongo Din ${ }^{1}$

${ }^{1}$ Laboratory of Biology and Physiology of Plant Organisms, Faculty of sciences, University of Douala, Cameroon, P.O. BOX 24157 Douala, Cameroon ${ }^{2}$ Pharmaceutical Science Laboratory, Department of Pharmaceutical Sciences, Faculty of Medicine and Pharmaceutical University of Douala, P.O. BOX 2701 Douala, Cameroon

${ }^{3}$ Laboratory of Botany and traditional medicine, Institute of Medical Research and study of Medicinal Plants, PO.BOX 13033 Yaounde, Cameroon

${ }^{4}$ Laboratory of Microbiology, Department of Biochemistry, University of Yaoundé I, P.O. BOX 812 Yaoundé, Cameroon

${ }^{5}$ Institute of Fisheries Science, Yabassi, Cameroon

DOI: 1 10.36348/sjls.2021.v06i02.001 | Received: 20.01.2021 | Accepted: 01.02.2020 | Published: 05.02 .2021

*Corresponding author: Ladoh-Yemeda Christelle Flora

\section{Abstract}

The work aimed to evaluate the antibacterial activity of Phragmanthera capitata (Loranthaceae) extracts harvested from 03 host plants (Psidium guajava, Cirus sinensis and Theobroma cacao) traditionally used in the treatment of a wide spectrum of diseases. The phytochemical screening of the extracts was determined using standard reference methods. The antibacterial activity of the extracts was evaluated by disk diffusion and liquid microdilution methods on 07 bacterial isolates. Qualitative phytochemical analysis indicated the presence of flavonoids, tannins, sterols, phenols and polyphenols in all extracts of $P$. capitata. The evaluation of the antibacterial activity showed that the extracts from the stems and haustoria of $P$. capitata collected from the three host plants are more active than the leaves for all the strains tested. This study shows that $P$. capitata despite its pernicious character could be a source of useful compounds for the fight against bacterial diseases.

Keywords: Phragmanthera capitata, Phytochemical screening, Antibacterial activity, African mistletoe, Loranthaceae, host plants.

Copyright (C) 2021 The Author(s): This is an open-access article distributed under the terms of the Creative Commons Attribution 4.0 International License (CC BY-NC 4.0) which permits unrestricted use, distribution, and reproduction in any medium for non-commercial use provided the original author and source are credited.

\section{INTRODUCTION}

Parasitism by Loranthaceae is a widespread ecological problem around the world [1]. Loranthaceae, commonly known as "African mistletoe" are chlorophyllian parasitic plants which attach themselves to the branches of their hosts via a sucker called haustoria, constituting a real physiological and structural bridge between the parasite and its host [2]. Parasites inflict on their hosts a diversion of water and nutritional substances essential to their life. This situation results in hypotrophy and wasting of the distal part of the host branch [3]. They cause a general weakening of host trees characterized by decreased growth in height and diameter, reduced flowering, fruiting and production of the host, and water loss which can lead to death of the distal part of the parasitized branches [4]. Mechanical, chemical, biological and even integrated control strategies have been developed to eradicate or at least reduce the invasion of these parasites in crops. These methods all have shown their limits [5, 6]. Phragmanthera capitata is a ubiquitous and very devastating plant whose remarkable ubiquity is suitable for all ecological variations in Cameroon [7-9]. Very invasive on parasitized host trees, this species has a very wide host spectrum compared to other Loranthaceae species [7]. Despite its strong pernicious character, $P$. capitata is used in traditional medicine in the treatment of diseases such as cancer, diabetes, disorders of the female reproductive system, hypertension, hypotension, asthma, epilepsy and infectious diseases, the treatment of which very often depends on the plants it parasitizes [10-12]. Studies have shown that the medicinal properties of these plants are dependent on the plants they parasitize [13]. The increasingly growing resistance of pathogenic organisms to pharmaceutical products is pushing researchers to explore plants used in traditional medicine for their therapeutic properties [14]. In addition, the excessive and / or abusive use of antibiotics in livestock farming, agriculture and 
aquaculture contributes to antimicrobial resistance and promotes its spread in the environment, in the food chain and in humans [15]. Medicinal plants are now an alternative source in the search for new bioactive molecules. The aim of this study is to evaluate the antibacterial potential in vitro of the Phragmanthera capitata extracts collected from three host trees (Theobroma cacao, Citrus sinensis and Psidium guajava).

\section{Materials ANd Methods \\ Harvest}

The leaves, stems and haustoria of $P$. capitata were collected from three host trees (Citrus sinensis, Theobroma cacao and Psidium guajava) in December 2012, in the orchard of the chiefdom of Ndogbong, in Douala (Littoral, Cameroon). The identification was made at the Plant Biology and Physiology Laboratory of the University of Douala-Cameroon.

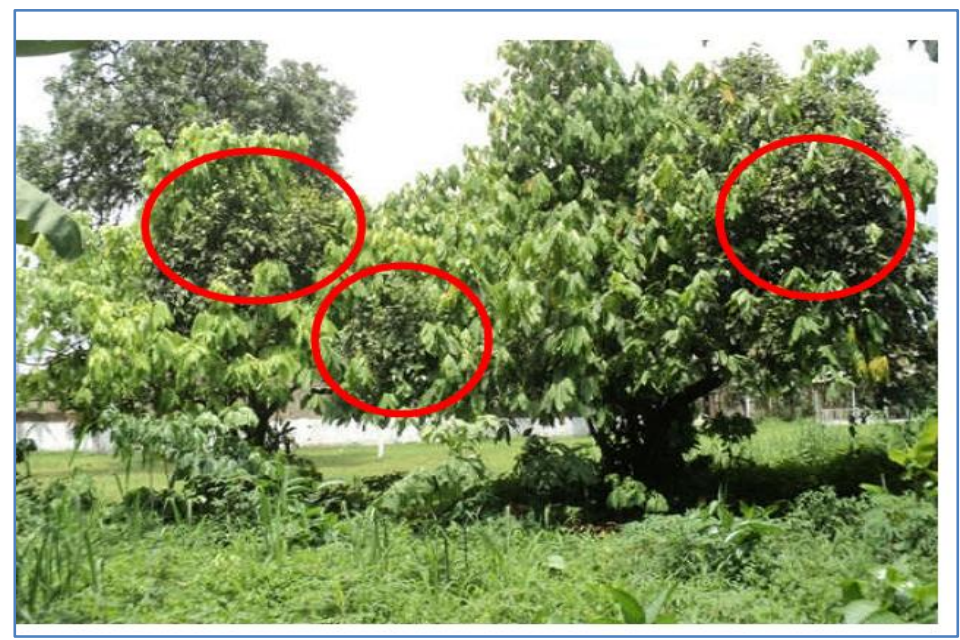

Fig-1: Theobroma cacao parasitized by Phragmanthera capitata

\section{Extraction}

The leaves, stems and haustoria of $P$. capitata were cut, dried at room temperature in the dark, and powdered. The powder from each part of the plant was macerated for $48 \mathrm{~h}$ in methanol. After maceration, the various mixtures were filtered through Whatman $\mathrm{N}^{\mathrm{o}} 1$ paper, in order to separate the marc from the filtrate. The filtrates were concentrated by rotary evaporation in a Heidolph brand rotavapor, the operation is repeated 3 times to obtain dry crude extracts.

\section{Preliminary phytochemical extracts screening}

The qualitative phytochemical study makes it possible to detect the presence of secondary metabolites in different parts of Phragmanthera capitata by coloring and precipitation reactions [16, 17]. Specifically, the extracts were screened for alkaloids, flavonoids, phenols, anthocyanins, coumarins, limonoids, tannins and saponins. Each of the tests was qualitatively expressed as absence (-) or presence (+).

\section{Assessment of the antibacterial activities of Phragmanthera capitata extracts \\ Bacterial strains tested}

The bacterial strains used include two reference strains from the American Type Culture Collection (ATCC) provided by the University of Marseille (Enterobacter aerugenes ATCC 13048 and Klebsiella pneumoniae ATCC 11296) and five clinical strains isolated from patients at the Institut Pasteur of Yaoundé-Cameroon (Bacillus cereus, Enterobacter cloacae, Escherichia coli, Klebsiella pneumoniae and
Staphylococcus aureus), all available at the Microbiology laboratory of the University of Yaoundé I-Cameroon.

\section{Disc diffusion in solid media}

The antibacterial activity of the Phragmanthera capitata leaves extracts, stems and haustoria collected from different host trees is determined according to the Kirby-Bauer method recommended by the NCCLS [18]. This method makes it possible to determine the sensitivity of bacteria to the extracts. The inoculum is prepared from a young culture of 18 to 24 hours incubated at $37^{\circ} \mathrm{C}$ on agar medium. A few bacterial colonies are suspended in physiological water $0.85 \% \mathrm{NaCl}$, and then stirred for a few seconds to make it homogeneous. The suspension is adjusted to a turbidity of an optical density corresponding to the 0.5 Mc Farland standards $\left(1 \times 10^{8} \mathrm{CFU} / \mathrm{mL}\right)$ with a spectrophotometer at $630 \mathrm{~nm}$, corresponding to an optical density ranging between 0.08 and 0.13 . Whatman filter paper discs $(6 \mathrm{~mm}$ in diameter) are sterilized in an autoclave then impregnated with $20 \mu \mathrm{L}$ of the extracts 50, 100, 200 and, $300 \mathrm{mg} / \mathrm{mL}$ corresponds to 1, 2, 4 and $6 \mathrm{mg} /$ disc. Gentamicin was used as a reference antibiotic at $500 \mu \mathrm{g} / \mathrm{mL}(10 \mu \mathrm{g} /$ disc). The culture medium was Mueller Hinton Agar with $\mathrm{pH}$ ajusted at 7.2 -7.4. The inoculation is done by swabbing the inoculum on the agar with tight streaks while rotating the dish $60^{\circ}$ three times to ensure good distribution. Then, the discs are placed in the dishes on the agar previously seeded. After 15 minutes of applying the disks, the Petri dishes are incubated at $37^{\circ}$ 
C for 18 to 24 hours. The tests are repeated 3 times, the results are read by measuring the diameters of the uniformly circular zones of inhibition $(\mathrm{mm})$ using a caliper [19]. The results are expressed as the average of the values obtained \pm the standard deviation. The sensitivity of the target bacteria to the different extracts was classified according to the diameters of the zones of inhibition: $\varnothing<8 \mathrm{~mm}$ : non-sensitive bacteria; $9<\varnothing$ $<14 \mathrm{~mm}$ : sensitive bacteria; $15<\varnothing<19 \mathrm{~mm}$ : very sensitive bacteria and $\varnothing>20 \mathrm{~mm}$ : extremely sensitive bacteria $[20,21]$.

\section{Microdilution in liquid medium}

The inhibition parameters of microbial growth by the extracts, which are minimum inhibitory concentrations (MIC) and bactericidal (MBC), are determined by the microdilution method using a colored indicator [22]. In each row of a 96-wells microplate, is introduced a volume of $100 \mu \mathrm{L}$ of Mueller Hinton broth. Then $100 \mu \mathrm{L}$ of the extract diluted in Mueller Hinton broth is added to the 1st well. After having thoroughly mixed the contents of the 1 st well, $100 \mu \mathrm{L}$ is taken, then placed in the 2nd well, and so on until the 6th well where the remaining $100 \mu \mathrm{L}$ is removed. Therefore, a $1 / 2$ dilution is obtained between each well with a final concentration range varying from 50$1.5625 \mathrm{mg} / \mathrm{mL}$. Finally, $100 \mu \mathrm{L}$ of the bacterial inoculum concentrated at $2 \times 10^{6} \mathrm{CFU} / \mathrm{mL}$ is introduced into each well. The last two wells represent negative controls: well $\mathrm{n}^{\circ} 7$ contains culture medium and inoculum and well $\mathrm{n}^{\circ} 8$ contains only Mueller Hinton broth. The microplates are sealed and incubated at $37^{\circ}$ $\mathrm{C}$ for $18-24 \mathrm{~h}$. The minimum inhibitory concentration (MIC) is determined by the use of iodonitrotetrazolium (INT) at $2 \mathrm{mg} / \mathrm{mL}$, which is a colorless reagent in its oxidized form. As they grow, bacteria release NADH into the medium, forming a pink color. The reaction is based on electron transfer; the MIC of the extract is the smallest concentration for which the color does not turn pink after addition of INT [23]. To determine the minimum bactericidal concentrations (MBC), a volume of $50 \mu \mathrm{L}$ of the contents of the wells at concentrations greater than or equal to the MIC, not having received INT was taken and then introduced into $150 \mu \mathrm{L}$ of broth in new microplates. The plates were then incubated for $48 \mathrm{~h}$ at $37^{\circ} \mathrm{C}$ followed by visualization at INT. All concentrations at which no pink coloration was observed were taken as bactericides. The smaller concentration is considered the minimum bactericidal concentration (MBC). The MBC / MIC ratio was used to determine the bactericidal (MBC / MIC < 4) or bacteriostatic ( $\mathrm{MBC} / \mathrm{MIC} \geq 4)$ effect of the substances tested [24].

\section{STATISTICAL ANALYSIS}

The results were statistically analyzed by the method of variance (ANOVA) using Statgraphic 5.0 software. The comparison of means is performed by the LSD (Least Significant Difference) test. The differences are significant when $\mathrm{p}<0.05$. The principal component analysis (PCA) by the XLStat 2007 software made it possible to reduce a complex data system into a small number of dimensions in order to visualize the similarities (or the correlation) between the antibacterial potential and the extracts of $P$ capitata collected from different host plants.

\section{RESULTS \\ Qualitative phytochemical analysis}

Phytochemical analysis revealed the presence of secondary metabolites in extracts of Phragmanthera capitata, a parasite of Psidium guajava (PcPsi), Theobroma cacao (PcTh) and Citrus sinensis (PcCi) (Table-1). Flavonoids, tannins, sterols, phenols and polyphenols are present in all extracts. Anthocyanins are also present in all extracts except PcTh and PcCi leaves. Coumarins, limonoids and saponins are present in all extracts of stems and haustoria and are absent in leaves extract of $P$. capitata from the three $(03)$ host plants. Alkaloids, on the other hand, are absent in all extracts.

Table-1: Phytochemical screening of Phragmanthera capitata extracts

\begin{tabular}{|c|c|c|c|c|c|c|c|c|c|}
\hline \multirow[t]{3}{*}{ P. capitata secondary metabolites } & & & & \multicolumn{3}{|c|}{ host plants } & & & \\
\hline & \multicolumn{3}{|c|}{ Psidium guajava } & \multicolumn{3}{|c|}{ Theobroma cacao } & \multicolumn{3}{|c|}{ Citrus sinensis } \\
\hline & $\mathrm{F}$ & $\mathrm{T}$ & $\mathrm{H}$ & $\mathrm{F}$ & $\mathrm{T}$ & $\mathrm{H}$ & $\mathrm{F}$ & $\mathrm{T}$ & $\mathrm{H}$ \\
\hline Alcaloids & - & - & - & - & - & - & - & - & - \\
\hline Phenols and polyphenols & + & + & + & + & + & + & + & + & + \\
\hline Flavonoids & + & + & + & + & + & + & + & + & + \\
\hline Tannins & + & + & + & + & + & + & + & + & + \\
\hline Anthocyanins & + & + & + & - & + & + & - & + & + \\
\hline Coumarins & - & + & + & - & + & + & - & + & + \\
\hline Limonoids & - & + & + & - & + & + & - & + & + \\
\hline Saponins & - & + & + & - & + & + & - & + & + \\
\hline Sterols & + & + & + & + & + & + & + & + & + \\
\hline
\end{tabular}

F: leaves; T: stems; H: haustoria; +: presence; - : absence 


\section{Evaluation of the antibacterial activity of Phragmanthera capitata extracts}

The results of the zones of inhibition diameters around the discs by the diffusion method indicate that the methanolic extracts of Phragmanthera capitata inhibited the growth of bacterial strains. It is also noted that these extracts exert a dose-dependent antibacterial activity which varies according to the organ of the parasite, the bacterial strains, the concentrations of extracts tested and the host plant, even if the diameters of the zones of inhibition are not always significantly different. Antibacterial activity by the disk diffusion method has been identified in a range of concentrations from 100 to $300 \mathrm{mg} / \mathrm{mL}$ or 1 to $6 \mathrm{mg} /$ disc. The extracts of $P$. capitata, a parasite of Psidium guajava (PcPsi) were active on six bacterial strains including one Gram- strain (Bacillus cereus) and five Gram + strains (Escherichia coli, Enterobacter cloaceae, E. aerugenes ATCC 13048, Klebsiella pneumoniae and K. pneumoniae ATCC 11296) with diameters of the zones of inhibition which varied from $7.17 \pm 0.35$ to $13.67 \pm$ $0.31 \mathrm{~mm}$ for the leaf extracts; $7.33 \pm 0.21$ to $15.67 \pm$ $0.49 \mathrm{~mm}$ for stem extracts and $7.07 \pm 0.21$ to $16.6 \pm$ $0.35 \mathrm{~mm}$ for haustoria extracts. However, E. cloaceae and $K$. pneumonia showed no sensitivity to leaf extracts. Stem and haustoria extracts were active against all bacterial strains at all concentrations tested except E. aerugenes ATCC 13048 which was resistant to $1 \mathrm{mg} /$ disc. B. cereus and E. coli are the most sensitive strains to different extracts. Staphylococcus aureus was resistant to all extracts of $P$. capitata, host of $P$. guajava (Table-2). The extracts of $P$. capitata, a parasite of Citrus sinensis (PcCi) were active on 4 bacterial strains including 2 Gram- and 2 Gram + strains (B. cereus, S. aureus, K. pneumoniae and $K$. pneumoniae ATCC 11296) with diameters of the zones of inhibition which varied from $7 \pm 0.5$ to $11 \pm 1.0 \mathrm{~mm}$ for the leaf extract; $6.5 \pm 0.1$ to $12.5 \pm 0.5 \mathrm{~mm}$ for the stem extract and $6.33 \pm 0.15$ to $12 \pm 1 \mathrm{~mm}$ for the extract of haustoria. E. coli, E. cloaceae and $E$. aerugenes ATCC 13048 were resistant to all extracts. Only the stem extract was active on $S$. aureus. $K$. pneumoniae and K. pneumoniae ATCC 11296 were the strains most sensitive to extracts of stems and haustoria, but also to extract of leaves from $4 \mathrm{mg} / \mathrm{disc}$. B. cereus is sensitive to the leaf extract from $4 \mathrm{mg} /$ disc (Table3).

The extracts of $P$. capitata, a parasite of Theobroma cacao (PcTh) were active on 2 bacterial strains including $1 \mathrm{Gram}-$ strain and $1 \mathrm{Gram}+\operatorname{strain}(B$. cereus and $K$. pneumoniae ATCC 11296) with diameters (inhibition zones) ranged from $6.5 \pm 0.1$ to 10 $\pm 0.2 \mathrm{~mm}$ for the leaves, $6.33 \pm 0.15$ to $8.33 \pm 0.31 \mathrm{~mm}$ for stem extracts and $6.33 \pm 0.21$ to $8.83 \pm 1.04 \mathrm{~mm}$ for haustoria extracts. S. aureus, E. cloaceae, E. coli, E. aerugenes ATCC 13048 and K. pneumoniae were resistant to all concentrations of the extracts. B. cereus was sensitive to leaf extract, starting at $6 \mathrm{mg} / \mathrm{disc}$, for stem extract and starting at $2 \mathrm{mg} /$ disc. Compared with
$P$. capitata extracts, gentamicin, the reference antibiotic, was significantly more active $(\mathrm{p}<0.05)$ on all strains tested with diameters of the zones of inhibition around the discs varying from $21.67 \pm 1.53$ at $37.33 \pm$ $1.53 \mathrm{~mm}$ (Table-4).

E. coli was very sensitive to extracts from stems and haustoria and sensitive to extracts from leaves of PcPsi. B. cereus was sensitive to all extracts except PcCi haustoria and PcTh stems. E. cloaceae and E. aerugenes ATCC 13048 were sensitive only to extracts from PcPsi stems; $K$. pneumoniae ATCC 11296 was sensitive to all extracts except extracts from $\mathrm{PcCi}$ and PcTh leaves. $K$. pneumoniae was only sensitive to extracts from the leaves, stems and haustoria of PcCi. Staphylococcus was sensitive only to $\mathrm{PcCi}$ stem extract. All the bacterial strains tested were extremely sensitive to gentamicin.

The main component analysis of the inhibition zones diameters of the different extracts makes it possible to group together the extracts of $P$. capitata according to their antibacterial potential which induce an inhibition of the bacterial strains tested (Figure-2). It emerges from this analysis 04 distinct groups representing the efficacy of extracts of $P$. capitata on the bacterial strains tested including group 1 (green), group 2 (red), group 3 (yellow) and group 4 (blue). Group I represents the most active extracts which include extracts of leaves (at 4 and $6 \mathrm{mg} /$ disc), stems and haustoria of PcPsi, followed by moderately active group II grouping together extracts of stems at 2, 4 and $6 \mathrm{mg} \mathrm{/} \mathrm{mL}$ of PcCi. Group III, the least active represented by extracts of leaves at 4 and $6 \mathrm{mg} / \mathrm{mL}$, stems at $1 \mathrm{mg} / \mathrm{mL}$ and haustoria of $\mathrm{PcCi}$ and group IV representing weakly active extracts: the extract of leaves at 1 and $2 \mathrm{mg} / \mathrm{mL}$ of PcPsi, 1 and $2 \mathrm{mg} / \mathrm{mL}$ PcCi leaves and all PcTh extracts. It turns out, taking into account the results of the inhibition diameters that the most active extracts are PcPsi extracts and the weakly active extracts are PcTh extracts.

The antibacterial activity of the $P$. capitata extracts is confirmed by the microdilution method which demonstrates the bactericidal or bacteriostatic character of the $P$. capitata extracts by determining the inhibition parameters, MIC (Minimum Inhibitory Concentration) and MBC ( Minimum Bactericidal Concentration) (Tables-5, 6-7). These concentrations ranged from 6.25 to $200 \mathrm{mg} / \mathrm{mL}$. MICs and CMBs of PcPsi extracts ranged from 6.25 to $50 \mathrm{mg} / \mathrm{mL}$, leaf extract ranged from 25 to $50 \mathrm{mg} / \mathrm{mL}$ while stem and haustoria extracts ranged from 6.25 at $50 \mathrm{mg} / \mathrm{mL}$. The MBC / MIC ratios strictly less than 4 show that the extracts of the leaves, stems and haustoria are bactericidal on the strains tested except $E$. cloaceae for the extract of the stems and B. cereus for the extract of haustoria where the ratio was equal to 4 signifying that these extracts are bacteriostatic on these strains. The $\mathrm{MBC}$, as well as the MBC / MIC ratio of stem extracts 
and haustoria on E. aerugenes strain ATCC 13048 could not be determined.

The MICs and MBCs of the $\mathrm{PcCi}$ extracts ranged from 12.5 to $200 \mathrm{mg} / \mathrm{mL}$. The MIC of the leaf extract was $200 \mathrm{mg} / \mathrm{mL}$ for K. pneumoniae and higher than $200 \mathrm{mg} / \mathrm{mL}$ for B. cereus, S. aureus and $K$. pneumoniae ATCC 11296, the MBCs as well as the MBC / MIC ratio could not be determined. The MICs of the PcTh extracts were higher than $200 \mathrm{mg} / \mathrm{mL}$ on the 2 strains tested (B. cereus and $K$. pneumoniae ATCC 11296). MBCs could not be determined. Gentamicin was bactericidal (MBC / MIC) on all strains tested.

Table-2: Inhibition zones diameters of the extracts of Phragmanthera capitata, a parasite of Psidium guajava on bacterial strains

\begin{tabular}{|c|c|c|c|c|c|c|c|c|}
\hline \multirow{2}{*}{$\begin{array}{l}P . \text { capitata } \\
\text { extracts }\end{array}$} & \multirow[b]{2}{*}{$\begin{array}{l}\text { Concentration } \\
\text { (mg/disc) }\end{array}$} & \multicolumn{7}{|c|}{ Diameters of inhibition zones (mm) } \\
\hline & & BC (-) & SA (-) & EClo (+) & $\mathrm{EC}(+)$ & EA (+) & $\mathbf{K P}(+)$ & $\mathbf{K P} *(+)$ \\
\hline \multirow{4}{*}{ Leaves } & 1 & $7.17^{\mathrm{a}} \pm 0.35$ & - & - & - & - & - & - \\
\hline & 2 & $\begin{array}{l}7.83^{\mathrm{ab}} \pm \\
0.67\end{array}$ & - & - & $7.67^{\mathrm{a}} \pm 0.42$ & - & - & $7.33^{\mathrm{a}} \pm 0.31$ \\
\hline & 4 & $8.67^{\mathrm{bc}} \pm 0.31$ & - & - & $12^{\mathrm{c}} \pm 1$ & - & - & $\begin{array}{l}7.67^{\mathrm{ab}} \pm \\
0.76\end{array}$ \\
\hline & 6 & $10.33^{\mathrm{de}} \pm 0.70$ & - & - & $13.67^{\mathrm{cd}} \pm 0.31$ & $8.17^{\mathrm{a}} \pm 0.76$ & - & $10^{\mathrm{de}} \pm 1$ \\
\hline \multirow{4}{*}{ Stems } & 1 & $9.33^{\text {cd }} \pm 0.31$ & - & $7.33^{\mathrm{ab}} \pm 0.21$ & $10^{\mathrm{b}} \pm 1$ & - & $7.5^{\mathrm{a}} \pm 1.32$ & $9^{\text {cd }} \pm 0.5$ \\
\hline & 2 & $11^{\mathrm{e}} \pm 0.50$ & - & $7.67^{\mathrm{ab}} \pm 0.76$ & $12.67^{\mathrm{c}} \pm 2.09$ & $9.83^{\mathrm{ab}} \pm 0.49$ & $9^{\mathrm{abc}} \pm 0.5$ & $10^{\mathrm{de}} \pm 1$ \\
\hline & 4 & $11.5^{\mathrm{e}} \pm 1.32$ & - & $8.33^{b c} \pm 0.31$ & $14.67^{\mathrm{de}} \pm 1.53$ & $\begin{array}{l}11.17^{\mathrm{bc}} \pm \\
1.04\end{array}$ & $10^{\mathrm{bcd}} \pm 1$ & $11^{\mathrm{e}} \pm 0.5$ \\
\hline & 6 & $11^{\mathrm{e}} \pm 0.60$ & - & $9^{c} \pm 0.5$ & $15.67^{\mathrm{e}} \pm 0.49$ & $\begin{array}{l}12.33^{\mathrm{c}} \pm \\
0.31\end{array}$ & $\begin{array}{l}10.33^{\text {cd }} \pm \\
0.31\end{array}$ & $\begin{array}{l}12.67^{\mathrm{f}} \pm \\
0.76\end{array}$ \\
\hline \multirow{4}{*}{ Haustoria } & 1 & $11^{\mathrm{e}} \pm 0.50$ & - & $7.07^{\mathrm{a}} \pm 0.21$ & $9.67^{b} \pm 1.53$ & - & $7.67^{\mathrm{a}} \pm 0.31$ & $\begin{array}{l}8.67^{b c} \pm \\
0.31\end{array}$ \\
\hline & 2 & $14.5^{\mathrm{f}} \pm 1.32$ & - & $7.33^{\mathrm{ab}} \pm 0.42$ & $12.67^{\mathrm{c}} \pm 1.53$ & $8.17^{\mathrm{a}} \pm 0.76$ & $8.67^{\mathrm{ab}} \pm 0.76$ & $10^{\mathrm{de}} \pm 1$ \\
\hline & 4 & $13.83^{\mathrm{f}} \pm 0.76$ & - & $7.67^{\mathrm{ab}} \pm 0.31$ & $16.6^{\mathrm{e}} \pm 0.35$ & $9.5^{\mathrm{ab}} \pm 0.5$ & $9.67^{\text {bc }} \pm 1.53$ & $10.5^{\mathrm{e}} \pm 0.5$ \\
\hline & 6 & $14^{\mathrm{f}} \pm 0.5$ & - & $9.33^{\mathrm{c}} \pm 0.31$ & $15.67^{\mathrm{e}} \pm 0.31$ & $9.83^{\mathrm{ab}} \pm 0.76$ & $\begin{array}{l}11.33^{\mathrm{d}} \pm \\
0.76\end{array}$ & $\begin{array}{l}12.67^{\mathrm{f}} \pm \\
1.15\end{array}$ \\
\hline Gentamicin & $10 \mu \mathrm{g} / \mathrm{disc}$ & $27^{g} \pm 1$ & $\begin{array}{l}26.83 \pm \\
0.76\end{array}$ & $21.67^{\mathrm{d}} \pm 1.53$ & $37.33^{\mathrm{f}} \pm 1.53$ & $\begin{array}{l}29.67^{\mathrm{d}} \pm \\
2.08\end{array}$ & $25^{\mathrm{e}} \pm 1$ & $24^{\mathrm{g}} \pm 1$ \\
\hline
\end{tabular}

BC : Bacillus cereus ; EClo : Enterobacter cloacae ; EC : Escherichia coli; EA : Enterabacter aerugenes ATCC 13048; KP : Klebsiella pneumoniae ; KP* : Klebsiella pneumoniae ATCC 11296; (-) : Gram - ; (+) Gram +. - : no inhibition. The values are expressed as mean \pm standard deviation $(n=3)$. Numbers with the same letter in the same column are not significantly different $(\mathrm{p}$ $<0.05)$

Table-3: Inhibition zones diameters of the extracts of Phragmanthera capitata, a parasite of Citrus sinensis on bacterial strains

\begin{tabular}{|c|c|c|c|c|c|c|c|c|}
\hline \multirow{2}{*}{$\begin{array}{c}\text { P. capitata } \\
\text { extracts }\end{array}$} & & \multicolumn{7}{|c|}{ Diameters of inhibition zones (mm) } \\
\hline & $\begin{array}{l}\text { Concentration } \\
\text { (mg/disc) }\end{array}$ & BC (-) & SA (-) & EClo (+) & $\mathbf{E C}(+)$ & $\begin{array}{l}\text { EA } \\
(+)\end{array}$ & $\mathbf{K P}(+)$ & $\mathbf{K P} *(+)$ \\
\hline & 1 & - & - & - & - & - & - & - \\
\hline \multirow{4}{*}{ Leaves } & 2 & - & - & - & - & - & - & - \\
\hline & 4 & $7.5^{\mathrm{ab}} \pm 1.32$ & - & - & - & - & $8.33^{\mathrm{ab}} \pm 0.91$ & $7^{\mathrm{ab}} \pm 0.5$ \\
\hline & 6 & $9^{b} \pm 1$ & - & - & - & - & $11^{\mathrm{c}} \pm 1$ & $7.5^{\mathrm{bc}} \pm 0.5$ \\
\hline & 1 & $6.5^{\mathrm{a}} \pm 0.1$ & $10^{\mathrm{a}} \pm 1$ & - & - & - & $7^{\mathrm{a}} \pm 0.1$ & $7.67^{\mathrm{bc}} \pm 0.31$ \\
\hline \multirow[t]{4}{*}{ Stems } & 2 & $9.17^{b} \pm 0.76$ & $10.5^{\mathrm{ab}} \pm 0.5$ & - & - & - & $11^{\mathrm{c}} \pm 0.5$ & $10^{\mathrm{d}} \pm 0.5$ \\
\hline & 4 & $12.3^{\mathrm{c}} \pm 0.76$ & $11.83^{\mathrm{c}} \pm 0.76$ & - & - & - & $12.5^{\mathrm{c}} \pm 0.5$ & $11.67^{\mathrm{e}} \pm 0.76$ \\
\hline & 6 & $\begin{array}{c}11.67^{\mathrm{c}} \pm \\
1.53\end{array}$ & $11.5^{\mathrm{bc}} \pm 0.5$ & - & - & - & $11.83^{\mathrm{c}} \pm 0.76$ & $10^{\mathrm{d}} \pm 0.5$ \\
\hline & 1 & - & - & - & - & - & $9^{b} \pm 1$ & $6.33^{\mathrm{a}} \pm 0.15$ \\
\hline \multirow[t]{3}{*}{ Haustoria } & 2 & - & - & - & - & - & $9.33^{b} \pm 0.65$ & $7.83^{\mathrm{bc}} \pm 0.76$ \\
\hline & 4 & - & - & - & - & - & $11.33^{\mathrm{c}} \pm 1.52$ & $8.33^{\mathrm{c}} \pm 0.31$ \\
\hline & 6 & - & - & - & - & - & $12^{\mathrm{c}} \pm 1$ & $10.33^{\mathrm{d}} \pm 0.2$ \\
\hline Gentamicin & $10 \mu \mathrm{g} / \mathrm{disc}$ & $27^{d} \pm 1$ & $26.83^{d} \pm 0.76$ & $\begin{array}{c}21.67 \pm \\
1.53\end{array}$ & $\begin{array}{c}37.33 \pm \\
1.53\end{array}$ & $\begin{array}{l}29.67 \\
\pm 2.08\end{array}$ & $25^{\mathrm{d}} \pm 1$ & $24^{\mathrm{f}} \pm 1$ \\
\hline
\end{tabular}

BC : Bacillus cereus; EClo : Enterobacter cloacae ; EC : Escherichia coli; EA 13048 : Enterabacter aerugenes ATCC $13048 ;$ KP : Klebsiella pneumoniae; KP 11296 : Klebsiella pneumoniae ATCC 11296 ; (-) : Gram - ; (+) Gram +. - No inhibition. The values are expressed as mean \pm standard deviation $(n=3)$. Numbers with the same letter in the same column are not significantly different $(\mathrm{p}$ $<0.05)$ 
Table-4: Inhibition zones diameters of the extracts of Phragmanthera capitata, a parasite of Theobroma cacao on bacterial strains

\begin{tabular}{|c|c|c|c|c|c|c|c|c|}
\hline \multirow{2}{*}{$\begin{array}{l}P \text {. capitata } \\
\text { extract }\end{array}$} & & \multicolumn{7}{|c|}{ Diameters of inhibition zones (mm) } \\
\hline & $\begin{array}{c}\text { Concentration } \\
\text { (mg/disc) }\end{array}$ & BC (-) & SA (-) & $\begin{array}{c}\text { EClo } \\
(+)\end{array}$ & EC (+) & EA (+) & $\begin{array}{c}\mathbf{K P} \\
(+)\end{array}$ & $\mathbf{K P} *(+)$ \\
\hline & 1 & $7.17^{\mathrm{ab}} \pm 0.76$ & - & - & - & - & - & - \\
\hline \multirow[t]{4}{*}{ Leaves } & 2 & $7.83^{\text {bcd }} \pm 0.76$ & - & - & - & - & - & $6.5^{\mathrm{a}} \pm 0.1$ \\
\hline & 4 & $9^{\text {def }} \pm 0.1$ & - & - & - & - & - & $6.83^{\mathrm{a}} \pm 0.15$ \\
\hline & 6 & $10^{\mathrm{fgh}} \pm 0.2$ & - & - & - & - & - & $7.67^{b} \pm 0.31$ \\
\hline & 1 & - & - & - & - & - & - & - \\
\hline \multirow[t]{4}{*}{ Stems } & 2 & - & - & - & - & - & - & - \\
\hline & 4 & - & - & - & - & - & - & $6.33^{\mathrm{a}} \pm 0.15$ \\
\hline & 6 & $6.33^{\mathrm{a}} \pm 0.15$ & - & - & - & - & - & $8.33^{b} \pm 0.31$ \\
\hline & 1 & - & - & - & - & - & - & - \\
\hline \multirow[t]{3}{*}{ Haustoria } & 2 & $6.33^{\mathrm{a}} \pm 0.21$ & - & - & - & - & - & - \\
\hline & 4 & $7.83^{\text {bcd }} \pm 0.35$ & - & - & - & - & - & $6.5^{\mathrm{a}} \pm 0.5$ \\
\hline & 6 & $8.83^{\text {def }} \pm 1.04$ & - & - & - & - & & $8.33^{b} \pm 0.21$ \\
\hline Gentamicin & $10 \mu \mathrm{g} / \mathrm{disc}$ & $27^{g} \pm 1$ & $\begin{array}{c}26.83 \pm \\
0.76\end{array}$ & $\begin{array}{l}21.67 \pm \\
1.53\end{array}$ & $\begin{array}{c}37.33 \pm \\
1.53\end{array}$ & $\begin{array}{c}29.67 \pm \\
2.08\end{array}$ & $25 \pm 1$ & $24^{\mathrm{c}} \pm 1$ \\
\hline
\end{tabular}

BC : Bacillus cereus ; EClo : Enterobacter cloacae ; EC : Escherichia coli; EA : Enterabacter aerugenes ATCC 13048 ; KP :

Klebsiella pneumoniae ; KP* : Klebsiella pneumoniae ATCC 11296 ; (-) : Gram - ; (+) Gram +. - No inhibition. The values are expressed as mean \pm standard deviation $(\mathrm{n}=3)$. Numbers with the same letter in the same column are not significantly different $(\mathrm{p}$ $<0.05)$

PsiF, PsiT and PsiH: Leaves extracts, stems and haustoria of Psidium guajava, ThF, ThT and ThH: Leaves extracts, stems and haustoria of Theobroma cacao, $\mathrm{CiF}, \mathrm{CiT}$ and $\mathrm{CiH}$ : Leaves extracts, stems and haustoria of Citrus sinensis. The numbers 1, 2, 4 and 6 accompanying the extract codes represent the concentrations tested in $\mu \mathrm{g} / \mathrm{disc}$.

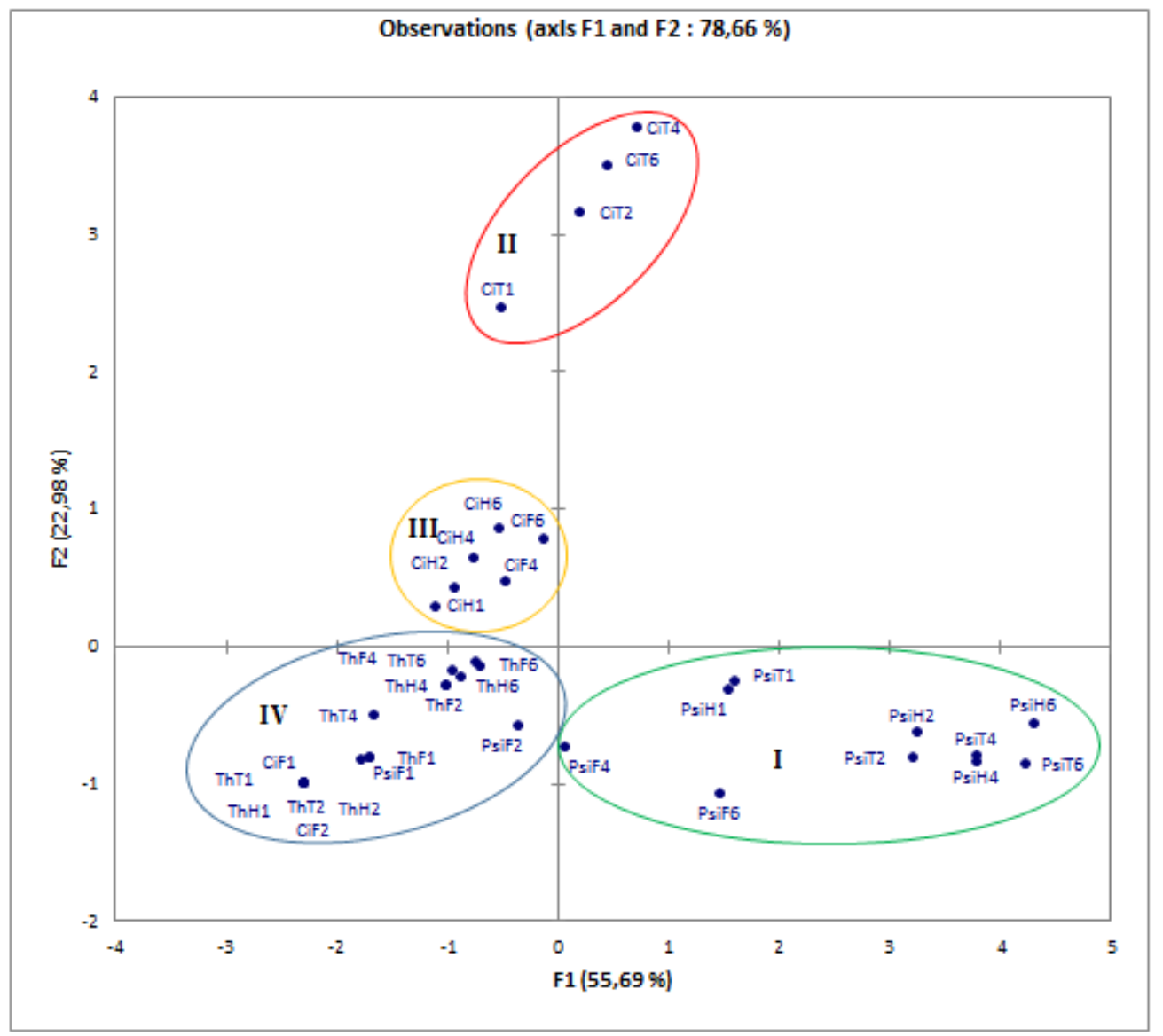

Fig-2: Principal component analysis based on the inhibitory activity of different extracts of Phragmanthera capitata at different concentrations on the bacterial strains tested 
Table-5: Inhibitory and bactericidal properties of extracts of Phragmanthera capitata, a parasite of Psidium guajava

\begin{tabular}{|c|c|c|c|c|c|c|c|c|c|c|c|c|}
\hline \multirow{2}{*}{$\begin{array}{c}\text { Bacterial } \\
\text { strains }\end{array}$} & \multicolumn{3}{|c|}{ Leaves $(\mathrm{mg} / \mathrm{mL})$} & \multicolumn{3}{|c|}{ Stem $(\mathrm{mg} / \mathrm{mL})$} & \multicolumn{3}{|c|}{ Haustoria (mg/mL) } & \multicolumn{3}{|c|}{ Gentamicin $(\mu \mathrm{g} / \mathrm{mL})$} \\
\hline & MIC & MBC & MBC/MIC & MIC & MBC & MBC/MIC & MIC & MBC & MBC/MIC & MIC & MBC & MBC/MIC \\
\hline BC & 25 & 25 & 1 & 6.25 & 12.5 & 2 & 6.25 & 25 & 4 & 62.5 & 62.5 & 1 \\
\hline EA* & 25 & 25 & 1 & 50 & nd & nd & 50 & nd & nd & $>125$ & nd & nd \\
\hline EClo & 25 & 50 & 2 & 12.5 & 50 & 4 & 25 & 50 & 2 & $>125$ & nd & nd \\
\hline EC & 50 & 50 & 1 & 6.25 & 6.25 & 1 & 50 & 50 & 1 & $>125$ & nd & nd \\
\hline KP & 50 & 50 & 1 & 50 & 50 & 1 & 50 & 50 & 1 & 31.25 & 62.5 & 2 \\
\hline KP* & 25 & 50 & 2 & 6.25 & 6.25 & 1 & 50 & 50 & 1 & 62.5 & 62.5 & 1 \\
\hline
\end{tabular}

BC : Bacillus cereus ; EClo : Enterobacter cloacae ; EC : Escherichia coli ; EA *: Enterabacter aerugenes ATCC 13048 ; KP :

Klebsiella pneumoniae ; KP* : Klebsiella pneumoniae ATCC 11296 ; MIC : Minimum inhibitory concentration ; MBC : Minimum bactericidal concentration.

Table-6: Inhibitory and bactericidal properties of extracts of Phragmanthera capitata, a parasite of Citrus sinensis

\begin{tabular}{|c|c|c|c|c|c|c|c|c|c|c|c|c|}
\hline \multirow[t]{2}{*}{ Bacterial strains } & \multicolumn{3}{|c|}{ Leaves $(\mathrm{mg} / \mathrm{mL})$} & \multicolumn{3}{|c|}{ Stems $(\mathrm{mg} / \mathrm{mL})$} & \multicolumn{3}{|c|}{ Haustoria $(\mathrm{mg} / \mathrm{mL})$} & \multicolumn{3}{|c|}{ Gentamicin $(\mu \mathrm{g} / \mathrm{mL})$} \\
\hline & MIC & MBC & MBC/MIC & MIC & MBC & MBC/MIC & MIC & MBC & MBC/MIC & MIC & MBC & MBC/MIC \\
\hline $\mathrm{BC}$ & $>200$ & nd & nd & 12.5 & 25 & 2 & $>200$ & nd & nd & 62.5 & 62.5 & 1 \\
\hline KP & 200 & nd & nd & 200 & nd & nd & $>200$ & nd & nd & 31.25 & 62.5 & 2 \\
\hline $\mathrm{KP}^{*}$ & $>200$ & nd & nd & 25 & 50 & 2 & $>200$ & nd & nd & 62.5 & 62.5 & 1 \\
\hline SA & $>200$ & nd & nd & 25 & 50 & 2 & $>200$ & nd & nd & 15.62 & 31.25 & 2 \\
\hline
\end{tabular}

BC: Bacillus cereus; KP : Klebsiella pneumoniae ; KP* : Klebsiella pneumoniae ATCC 11296 ; MIC : Minimum inhibitory concentration ; MBC : Minimum bactericidal concentration.

Table-7: Inhibitory and bactericidal properties of extracts of Phragmanthera capitata, a parasite of Theobroma cacao

\begin{tabular}{|c|c|c|c|c|c|c|c|c|c|c|c|c|}
\hline \multirow[t]{2}{*}{ Bacterial strains } & \multicolumn{3}{|c|}{ Leaves $(\mathrm{mg} / \mathrm{mL})$} & \multicolumn{3}{|c|}{ Stems (mg/mL) } & \multicolumn{3}{|c|}{ Haustoria (mg/mL) } & \multicolumn{3}{|c|}{ Gentamicin $(\mu \mathrm{g} / \mathrm{mL})$} \\
\hline & MIC & MBC & MBC/MIC & MIC & MBC & MBC/MIC & MIC & MBC & MBC/MIC & MIC & MBC & MBC/MIC \\
\hline $\mathrm{BC}$ & $>200$ & nd & nd & $>200$ & nd & nd & $>200$ & nd & nd & 62.5 & 62.5 & 1 \\
\hline $\mathrm{KP}^{*}$ & $>200$ & nd & nd & $>200$ & nd & nd & $>200$ & nd & nd & 62.5 & 62.5 & 1 \\
\hline
\end{tabular}

BC : Bacillus cereus ; KP* : Klebsiella pneumoniae ATCC 11296 ; MIC : Minimum inhibitory concentration ; MBC : Minimum bactericidal concentration.

\section{DISCUSSION}

This study allowed evaluating the antibacterial activity of Phragmanthera capitata extracts collected from three (03) host plants out of seven (07) bacterial strains including two (02) reference strains and five (05) clinical strains. The results obtained indicate that the extracts of $P$. capitata harvested from Psidium guajava, Citrus sinensis and Theobroma cacao show different degrees of growth inhibition. These differences depend on the microbial strain, the concentration of extract tested, the parasite organ and the host plant. The strains: Bacillus cereus, Escherichia coli, Enterobacter cloaceae, E. aerugenes ATCC 13048, Klebsiella pneumoniae and K. pneumoniae ATCC 11296 had variable sensitivity depending on the extracts of $P$. capitata. On the other hand, Staphylococcus aureus has been shown to be resistant to all extracts except the stems of $P$. capitata harvested from Citrus sinensis. This difference is due to the difference in cell wall structure between Gram + bacteria and Gram- bacteria [25]. Generally speaking, Gram- bacteria, independently of the cell membrane (peptidoglycan), have an additional layer: the outer membrane, which is made up of phospholipids, proteins and lipopolysaccharides. This membrane is impermeable to most molecules. Peptidoglycan, on the other hand, is porous and allows many substances to pass through, which is not the case with the outer membrane of Gram-opposed bacteria. Consequently, this results in a higher resistance of Gram- strains against the activity of the prepared plant extracts [26, 27].
All the bacterial strains tested were extremely sensitive to the reference antibiotic gentamicin. On the other hand, the antibacterial activity of the extracts on the strains tested was very low compared to gentamicin, which can be explained by the fact that the standard is a pure compound compared to the extracts which are not pure, but crude [28, 29]. Holetz [30] and Toyang [31] consider that extracts with an MIC $<100 \mu \mathrm{g} / \mathrm{mL}$ have good antibacterial activity; between $100<\mathrm{MIC}<500 \mu \mathrm{g}$ / $\mathrm{mL}$, moderate activity; $500<\mathrm{MIC}<1000 \mu \mathrm{g} / \mathrm{mL}$, low activity and finally inactive for MIC $>1000 \mu \mathrm{g} / \mathrm{mL}$.

The smallest MIC observed in this study is $6250 \mu \mathrm{g} / \mathrm{mL}$, which shows that the extracts of $P$. capitata have a relative activity on the strains tested, although the MBC / MIC ratio has shown that these extracts are bactericidal. These results are in agreement with the work of Osadebe and Akabogu [32] who report that the methanolic extracts of Loranthus micranthus exhibited antibacterial activities against Bacillus subtilis and Escherichia coli with MICs of 1580 and $1480 \mu \mathrm{g} /$ $\mathrm{mL}$. On the other hand, Orhue [33] report that extracts from Tapinanthus dodoneifollus leaves harvested from T. cacao had MICs of 8.6 and $70 \mu \mathrm{g} / \mathrm{mL}$ on Klebsiella aerogenes and Staphylococcus aureus, respectively.

The absence of alkaloids in the extracts revealed by phytochemical analysis could also justify this relative activity of $P$. capitata. Soheil [34] noted an antibacterial activity of extracts of Loranthus micranthus, a parasite of Cola acuminata and Persea americana. They indicate an abundance of alkaloids in these extracts and point out that this is responsible for 
their antimicrobial activity. Yusuf [35] also note that Viscum album harvested from Theobroma cacao had a higher antibacterial activity than $V$. album harvested from Cola nitida, and justify this activity by the presence of the alkaloids in extracts of $V$. album harvested from Theobroma cacao. The relative activity of the extracts on the bacterial strains tested in this study could justify the low use of $P$. capitata in the treatment of infectious diseases revealed by ethnobotanical surveys [12]. It is necessary to specify that a result observed during the evaluation of a raw extract is the component of two parameters: the intrinsic activity of a product, on the one hand, and on the other hand, its relative quantity in the extract. Thus, the marked activity of an extract may just as well come from a small amount of very active constituents, as from a large amount of low active constituents. In addition, an observed activity may result from the sum of the activities of several constituents [36, 37].

\section{CONCLUSION}

The phytochemical screening of the extracts of $P$. capitata collected from the different hosts showed the presence of a variety of secondary metabolites such as flavonoids, phenols, tannins, anthocyanins and sterols in all extracts except for alkaloids. The evaluation of the antibacterial and antioxidant properties in vitro showed that stems and haustoria extracts are more active than those of leaves and this variation is also observed depending on the host plant. The results show that although the extracts of $P$. capitata reduce the proliferation of the bacterial strains tested but at very high doses, these extracts appear to have a low antibacterial potential. It would be wise to conduct further studies by performing bioguided fractionations of the active extracts in order to characterize and isolate the compounds from the fractions that will be shown to be active by more efficient methods.

\section{REFERENCES}

1. Polhill, R.M., Wiens, W. (1998). Mistletoes of Africa. R.oyal Bot. Gardens, Kew. 370.

2. Sallé, G., Tuquet, C., Raynal-Roques, A. (1998). Biologie des Phanérogames parasites. C. R. Soc.

3. Sallé, G. (1994). Mission Loranthacées, Rapport de la mission réalisée au Cameroun du 10-19 mars 1994.

4. Zermane, N. (1998). Contribution à l'étude des phanérogames parasites de l'Algérie: Inventaire, répartition géographique, plantes hôtes, dégâts et quelques méthodes de lutte. Thèse de Magister en Sciences Agronomiques. Option: Phytopathologie. Ina elharrach. Alger, 219.

5. Dembele, B., Raynal-Roques, A., Sallé, G., Tuquet, C. (1994). Plantes parasites des cultures et des semences forestières au Sahel, Institut du Sahel/CTA, 43.

6. Ladoh, Yemeda, C.F., Mony, R., Tchatat, M., Dibong, S.D. (2013). Contribution des fourmis à la lutte biologique contre les Loranthaceae. Int. J. Biol Chem Sci, 7(3): 924-937.

7. Dibong, S.D., Din, Ndongo., Priso, R.J., Taffouo, V.D., Fankem, H., Salle, G., Amougou Akoa. (2008. Parasitism of host trees by the Loranthaceae in the region of Douala (Cameroon). Afr. J. Environ. Sci. Technol, 2(11): 371-378.

8. Denis-Esdras, A. A., Fofana, S. E. G. U. E. N. A., Kafana, S. O. R. O., Dodiomon, S. O. R. O., \& Koffi, N. G. (2017). Ethnobotany study of Loranthaceae, hemiparasitic plants used in traditional medicine by population, in the SudComoé region (Côte d'Ivoire). Journal of Medicinal Plants, 5(5), 215-222.

9. Soro, K., Soro, D., N'guessan, K., Gnahoua, G. M., \& Traoré, D. (2010). Parasitisme des Loranthaceae sur les hévéas en zone forestière des sous-préfectures de Gagnoa et d'Ouragahio, en Côte d'Ivoire. J. Anim. Plant Sci, 6(1), 597-604.

10. Didier, D. S., Laurier, E. O. N., Din, N., Jules, P. R., Victor, T., Henri, F., ... \& Akoa, A. (2009). An assessment on the uses of Loranthaceae in ethno pharmacology in Cameroon: A case study made in Logbessou, North of Douala. Journal of Medicinal Plants Research, 3(8), 592-595.

11. Azo'o, J. R. N., Tchatat, M., Mony, R., \& Dibong, S. D. (2013). Parasitisme et ethnobotanique des Loranthaceae à Lokomo (Est-Cameroun). Journal of animal and plant sciences, 19(2), 2923-2932.

12. Flora, L. Y. C., Din, N., \& Minette, T. E. (2019). Medicinal Potentials of Phragmanthera capitata (Sprengel) S. balle (Loranthaceae) Used in the City of Douala (Cameroon). Life Sci, 4(1), 1-14.

13. Ladokun, O. A., Olufunso, O.S., Ojezele, O. M. (2015). Biochemical composition of mistletoe as affected by hosts (Cocoa, kola and coffee tree). Report and Opinion, 7(6), 4.

14. Hoffman, S. J., \& Røttingen, J. A. (2015). Observatoire de la santé mondiale. Bulletin de l'Organisation mondiale de la Santé, 93, 66.

15. FAO. (2016). La résistance aux antibiotiques. http://www.fao.org/3/a-bc310f.pdf. (En ligne). Page consultée 26 septembre 2016.

16. Sofowora, A. (1993). Medicinal plants and Traditional Medicine in Africa. Spectrum Books, badan.

17. Harbone, J.B. (1998). Phytochemical methods. À guide to modern techniques of plants analysis. Third edition. Chapman and Hall. London. 150.

18. NCCLS. (2000). Performance standards for antimicrobial disc susceptibility tests: Approval standard M2-A7 $7^{\text {th }}$ edition. Pennsylvania: Clinical and Laboratory Standards Institute.

19. CLSI. (2006). Clinical and Laboratory Standards Institute. Methods for dilution antimicrobial susceptibility testing for bacteria that grows aerobically. Approved standard M7-A7, Clinical and Laboratory Standards Institute, Wayne, PA, 26: 2 . 
20. Moreira, M. R., Ponce, A. G., del, Valle, Roura, S. I. (2005). Inhibitory parameters of essentials oils to reduce foodborne pathogen. LWT - Food Sci Tech, 38(5): 565-570.

21. Ponce, A. G., Fritz, R., Del Valle, C., \& Roura, S. I. (2003). Antimicrobial activity of essential oils on the native microflora of organic Swiss chard. LWT-Food Science and Technology, 36(7), 679-684.

22. Eloff, J. N. (1998). A sensitive and quick microplate method to determine the minimal inhibitory concentration of plant extracts for bacteria. Planta medica, 64(08), 711-713.

23. Atindehou, M. (2012). Caractérisation structurale et biologique de nouveaux agents antibactériens naturels actifs dans les infections intestinales: des peptides de la chromogranine A et des principes actifs de Chromolaena odorata (Doctoral dissertation, Université de Strasbourg).

24. Fauchère I. L., Avril J. L. (2002). Bactériologie générale et médicale. Editions Ellipses: Paris.

25. Cushnie, T. T., \& Lamb, A. J. (2011). Recent advances in understanding the antibacterial properties of flavonoids. International journal of antimicrobial agents, 38(2), 99-107. Cushnie, T. T., \& Lamb, A. J. (2011). Recent advances in understanding the antibacterial properties of flavonoids. International journal of antimicrobial agents, 38(2), 99-107.

26. Kumar, V. P., Chauhan, N. S., Padh, H., \& Rajani, M. (2006). Search for antibacterial and antifungal agents from selected Indian medicinal plants. Journal of ethnopharmacology, 107(2), 182-188.

27. Ghedadba, N., Hambaba, L., Ayachi, A., Aberkane, M. C., Bousselsela, H., \& OueldMokhtar, S. M. (2015). Polyphénols totaux, activités antioxydante et antimicrobienne des extraits des feuilles de Marrubium deserti de Noé. Phytothérapie, 13(2), 118-129.

28. Fabry, W., Okemo, P. O., \& Ansorg, R. (1998). Antibacterial activity of East African medicinal plants. Journal of ethnopharmacology, 60(1), 7984.

29. Rokia, S., Drissa, D., Seydou, D., Colette, E., \& Flabou, B. (2006). Activite antibacterienne et antalgique de deux recettes traditionnelles utilisees dans le traitement des infections urinaires et la cystite au Mali. Mali Médical, 21(1), 18.

30. Holetz, F. B., Pessini, G. L., Sanches, N. R., Cortez, D. A. G., Nakamura, C. V., \& Dias Filho, B. P. (2002). Screening of some plants used in the Brazilian folk medicine for the treatment of infectious diseases. Memórias do Instituto Oswaldo Cruz, 97(7), 1027-1031.

31. Toyang, N. J., Ateh, E. N., Keiser, J., Vargas, M., Bach, H., Tane, P., ... \& Verpoorte, R. (2012). Toxicity, antimicrobial and anthelmintic activities of Vernonia guineensis Benth.(Asteraceae) crude extracts. Journal of Ethnopharmacology, 144(3), 700-704.

32. Osadebe, P. O., \& Akabogu, I. C. (2006). Antimicrobial activity of Loranthus micranthus harvested from kola nut tree. Fitoterapia, 77(1), 54-56.

33. Orhue, P. O., Edomwande, E. C., Igbinosa, E., Momoh, A. R. M., \& Asekomhe, O. O. (2014). Antibacterial activity of extracts of mistletoe (Tapinanthus dodoneifollus (dc) dancer) from cocoa tree (Theobrama cacao). International Journal of Herbs and Pharmacological Research, 3(1), 24-29.

34. Zorofchian Moghadamtousi, S., Hajrezaei, M., Abdul Kadir, H., \& Zandi, K. (2013). Loranthus micranthus Linn.: biological activities and phytochemistry. Evidence-Based Complementary and Alternative Medicine, 2013.

35. Yusuf, L., Oladunmoye, M. K., Ogundare, A. O., Akinyosoye, F. A., Daudu, O. A. Y., \& Hassan, G. A. (2013). Antimicrobial and antioxidant properties of mistletoe (Viscum album) growing on cola (Cola nitida) tree in Akure North, Nigeria. J Microbiol Res Rev, 1(3), 35-41.

36. Cavin, A. L. (2007). Contribution à la connaissance taxonomique et chimique de fruits africains du genre" Detarium"(FabaceaeCaesalpinioideae):" D. microcarpum" Guill. et Perr. et des formes comestibles et toxiques de" D. senegalense" JF Gmel (Doctoral dissertation, University of Geneva).

37. Sokół-Łętowska, A., Oszmiański, J., \& Wojdyło, A. (2007). Antioxidant activity of the phenolic compound of hawthorn, pine and skullcap. Food chemistry, 103(3), 853-859. 